\section{Cartoon Editorial}

Check for updates

\section{OPEN ACCESS}

Received: Nov 4, 2019

Accepted: Nov 12, 2019

Address for Correspondence:

Min Suk Chung, MD, PhD

Department of Anatomy, Ajou University

School of Medicine, 164 World Cup-ro,

Yeongtong-gu, Suwon 16499,

Republic of Korea.

E-mail: dissect@ajou.ac.kr

c 2019 The Korean Academy of Medical

Sciences.

This is an Open Access article distributed under the terms of the Creative Commons Attribution Non-Commercial License (https:// creativecommons.org/licenses/by-nc/4.0/) which permits unrestricted non-commercial use, distribution, and reproduction in any medium, provided the original work is properly cited.

ORCID iD

Min Suk Chung (iD

https://orcid.org/0000-0002-0527-9763

\section{Disclosure}

The author has no potential conflicts of interest to disclose.

\title{
Knowledge and Environment for Breast Feeding
}

\author{
Min Suk Chung (D)
}

Department of Anatomy, Ajou University School of Medicine, Suwon, Korea

- See the article "Breastfeeding Knowledge, Attitude, and Practice among White-Collar and Blue-Collar Workers in Indonesia" in volume 34, number 45, e284.

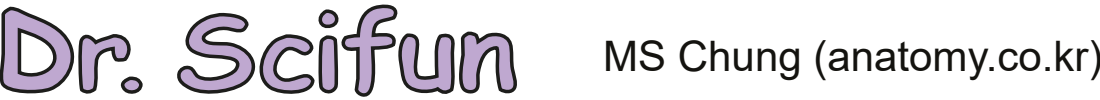

Knowledge and environment for breast feeding

White-collar workers have better knowledge and practice toward breast feeding than blue-collar workers.

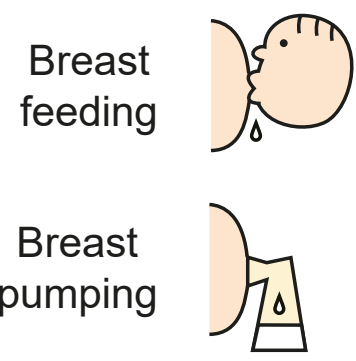

In addition, workers need to be provided with good environment.

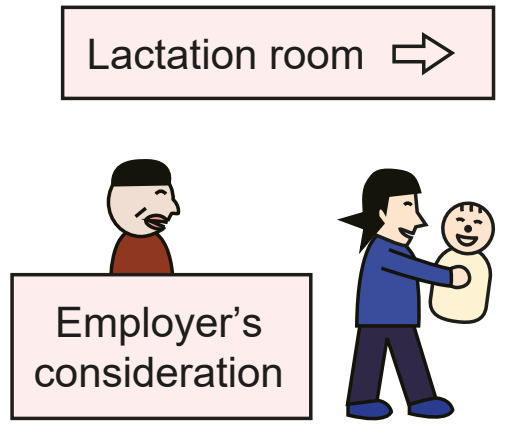

To promote the breast feeding, workers need to be equipped with knowledge.

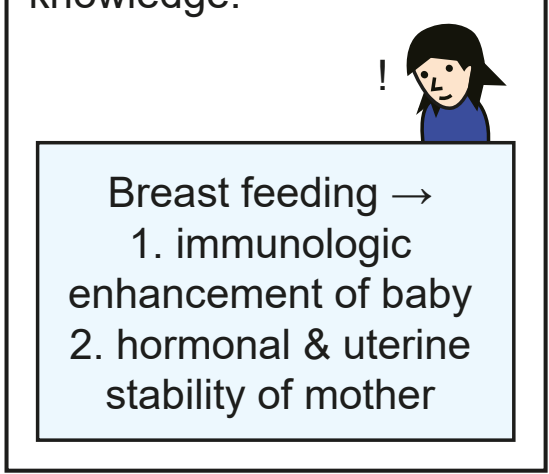

Knowledge and environment contribute to the maternal and child health of both white-collar and blue-collar workers.

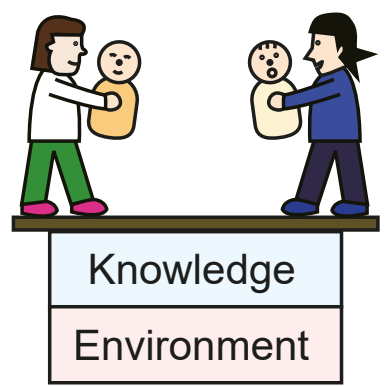

